\title{
Labour market deregulation in Fiji
}

\author{
Ganesh Chand
}

\section{Introduction}

In 1991, the military-backed Interim Government in Fiji promulgated numerous decrees that substantially amended the labour legislation of the country. The decrees were a part of a wider set of policies designed to deregulate the labour market, which in turn formed a component of a package of structural adjustment policies. The overall objective of these policies was to reassert the role of an unhindered market mechanism in allocating resources. In Fiji, this objective was to be achieved in various areas. In the public sector, the role of the government was to be reduced; towards this objective, all publicly owned ventures were to be gradually corporatised and eventually privatised. To provide incentives to the private sector, an indirect tax system was to take over from reliance on direct, and particularly income, taxes. In trade, protective policies were to be eliminated and the international market was to determine the prices of imports and exports. In the labour market, the free play of the forces of supply and demand was to determine labour utilisation and remuneration.

While the policy shift towards structural adjustment had begun to be gradually implemented in Fiji in the mid 1980s, it was the military coup of 1987 and the subsequent collapse of the economy that provided the impetus for a rapid implementation of these policies. By the end of 1988, the Interim Government had announced that it was escalating the pace of implementing these policies, in order to revive economic growth. The cornerstone of the revival was to be export- 
oriented industrialisation. For this to succeed, the government emphasised the need to foster a wage-competitive economy. It was from this perspective that labour market deregulation policies were developed.

For many years prior to the military coups national wage guidelines had been established, either through tripartite negotiations, through government initiative, or through semi-autonomous wages councils. However, within the new economic environment which followed the coups the government began to view such processes of wage determination as being 'not consistent with the flexibility and commercial realism required in different industries to retain a competitive position' (Government of the Republic of Fiji 1993:6). A new agenda was thus developed, a cornerstone of which was labour market deregulation.

Labour market deregulation is an attempt by the state to free the determination of workers' wages from the influence of 'distortionary' institutions like trade unions. A totally deregulated labour market is one where only the worker and the employer determine the wages of the worker, through a process of decentralised bargaining. Wage levels are set through the interplay of labour market demand and labour market supply, which establish an 'equilibrium' wage which 'clears' the labour market. In principle, the equilibrium wage should reflect productivity of the workers. This theoretical perspective informed policy. When delivering his 1991 budget address, the Finance Minister announced that the regime was deregulating the wage settlement process. He argued that a primary cause of distortions in the labour market was 'excessive and uncontrolled union intervention' (Ministry of Finance 1991:21). Policies announced in the budget were followed up, during 1991 and 1992 in particular. The essence of the changes in the policy framework was to limit the influence of trade unions on the functioning of the labour market.

This chapter examines what labour market deregulation has entailed, the reasons for the reforms, and the impact of the reforms on the functioning of the labour market. It demonstrates that labour market deregulation has had a significant effect upon the rate of unionisation, upon strikes and industrial disputes, upon employee remuneration, and upon the structure of employment. The chapter recognises that the new Constitutional settlement has repealed many of the amendments to labour law, which were responsible for these 
changes. The new government may also move to repeal some of changes to labour law enacted in the early 1990s. Nonetheless, in that the operation of the labour market has fundamentally changed, the impact of deregulation will continue to be felt.

\section{The post-independence labour market}

At independence in 1970 the labour market in Fiji was regulated by a set of laws which were inherited from the colonial power, Britain. The key acts regulating the labour market were the Wages Council Act of 1960, the Trade Unions Act of 1964, the Employment Act of 1965, the Workmen's Compensation Act of 1965, and the Shop (Regulations of Hours and Employment) Act of 1965. In the immediate postindependence period, the scope of this legislative framework was considerably enlarged, as state intervention in the labour market deepened.

In part, expanded state intervention in the labour market was designed to offset increased labour militancy. The inflation rate rose from 4.1 per cent in 1970 to 6.5 per cent in 1972, 9.1 per cent in 1973, 11.2 per cent in 1974 and a peak of 14.4 per cent in 1975 (Fiji Bureau of Statistics, various issues (a)). The increase in inflation coincided with growth in formal employment outstripping growth in the labour force (Chand 1996). In a situation of an increasingly tight labour market, worker solidarity increased and the unionisation rate rose in successive years following independence. In large part, worker solidarity increased because most of the post-1959 ethnically based unions had already collapsed by the late 1960s. The trade union movement was increasingly cutting across ethnic barriers, and worker solidarity was on the rise. Unions, with increasing success, militantly pressed the case for improvements in the terms and conditions governing the employment of labour. In 1971 a record number of strikes took place, and a record number of workdays were lost. In subsequent years, strike activity and lost workdays increased so that by 1975, 46 strikes took place involving 12,180 workers and resulting in 57,373 lost working days (Chand 1997). To a large extent, organised labour was successful in pressing its case for improved living standards. The average annual increase in daily wages for the years 1966 to 1970 had been 6.2 per cent. For the years 1971 to 1975, this jumped to 19.5 per cent (Chand 1996). 
In that price rises played a pivotal role in sustaining increased labour militancy, the post-colonial state rapidly sought to intervene to limit price rises. In April 1971, under Price Control Legislation, the Government placed certain commodities under price controls. While the range of controls was not very broad, it indicated the beginning of a deeper intervention into both product and labour markets. In 1972 the Prime Minister's working party on unemployment recommended that a Prices and Incomes Board be formed to monitor prices in Fiji and, where necessary, set price controls. The Prices and Incomes Board was established in 1973. It was accompanied by a Counter Inflation Act, which imposed a wage and salary freeze for the year. At the same time, a Trade Disputes Act was passed. Its stated objectives were to provide an 'efficient' system for resolving industrial disputes through conciliation, voluntary mediation, and arbitration; to encourage the voluntary use of third parties by unions and employers so that solutions to differences that they could not solve between themselves might be found; and to provide powers to both the Minister and the Permanent Secretary for Labour and Industrial Relations to intervene in trade disputes, in order to facilitate an early settlement. Clearly, the state rapidly sought to regulate the activities of organised labour. In this light, it is not surprising that the Fiji Trades Union Congress (FTUC), the umbrella body of trade unions in the country, opposed the Trade Disputes Act: it placed limits on the use of industrial action as a tool for workers to improve their terms and conditions of employment. The FTUC held that the Act would 'result in a virtual stranglehold on trade unions. It will lead to reducing the free collective bargaining system to a farcical exercise' (FTUC 1976:9) ${ }^{1}$.

Soon after the legislative barrage of 1973, an Industrial Relations Code of Practice was drawn up. Receiving support from the Labour Advisory Board, the Code, though not a legally binding document, aimed at introducing a 'reasonable' and constructive environment for collective bargaining (Leckie 1988:140). Then, in 1976, a Trade Union (Recognition) Act was enacted, which laid down the procedure for the recognition of trade unions.

However, state efforts to regulate organised labour were not working. Workers in general, and public sector workers in particular, were not satisfied with the mechanisms developed by the state between 1971 and 1976. In response to increasing industrial disputes, growing unionisation, and a tense industrial relations climate, in 1976 
the Prime Minister, representatives of the FTUC and employers established a Tripartite Forum, in which all three stakeholders were represented. In a sense, attempts by the state to unilaterally regulate the labour market were abandoned and organised labour was formally recognised as a social partner. From 1977 until 1984 the Forum was the single most important institution for wage negotiations in Fiji, developing in particular an institutional framework for the determination of national wage guidelines. The establishment of Wages Councils for various industrial sectors, and the setting of minimum wage guidelines complimented the Forum; both served to strengthen the institutional framework for determining labour incomes in Fiji.

\section{Why reform?}

Following the 1979 oil price shock, unstable international prices for Fiji's main export, sugar, and a series of natural disasters, the early 1980s witnessed visible signs of economic stagnation. As economic performance deteriorated, union organisation deepened. In the mid 1970s, the unionisation rate was about 44 per cent. The unionisation rate increased to a peak of 49 per cent in 1982 (Chand 1996). When, in the early 1980s, and following advice from international consultants and multilateral organisations, the government began re-examining the role of the state in light of poor economic performance, the labour market came under particular scrutiny. In line with an emerging neoliberal consensus in the developed market economies, trade unions came to be increasingly viewed in official circles as institutions that create distortions in what would otherwise be a reasonably 'efficient' labour market. Such distortions, it was argued, were primarily responsible for inflation and poor economic performance. In this context, and with a sluggish economy, it came as little surprise when the Government in November 1984 unilaterally imposed a wage freeze and effectively terminated the Tripartite Forum. The 1984 wage freeze heralded the beginning of a new era in economic policy in Fiji: that of structural adjustment.

As a consequence of the wage freeze, the trade union movement announced plans for the launching of a political organisation to safeguard its interests in the legislature. The Fiji Labour Party (FLP), organised and formally launched by the FTUC in 1986, went on to win the 1987 national elections in coalition with the National Federation 
Party (NFP). When a military coup deposed the newly elected government in May 1987, most of the trade union leaders behind the FLP and the FTUC began to play an active role in opposing the coup, through the promotion of a movement for the restoration of democracy. International union solidarity also became a useful tool in pressuring the military-backed regime to return power to a democratically elected government.

The coups led to the collapse of the national economy (Sepehri and Akram-Lodhi, this volume). Given this, a new economic policy package designed to revive the economy was put in place in 1989. The structural adjustment process, which had begun prior to the coups, was accelerated, with the aim of transforming Fiji from an inward looking economy into one that relied on export processing. The most important ingredient in the proposed transformation of the economy was to be the creation of wage-competitiveness with respect to other export processing economies around the Pacific Rim.

To this end, labour law amendments were promulgated in 1991 and 1992. These sought to address two concerns simultaneously. First, by weakening trade unionism, the military-backed regime thought it would weaken opposition to its rule. Second, by weakening trade unionism, union induced upward pressure on wages would be weakened, promoting greater wage competitiveness with respect to other export processing economies.

\section{Ingredients of the reforms}

In 1991 and 1992 the Industrial Associations Act, the Trade Union (Recognition) Act, the Trade Unions (Collection of Union Dues) Regulations, the Trade Unions Act, the Trade Unions Regulations and the Trade Disputes Act were all amended so that the substance of each were substantially changed. The changes in each of these areas are examined in turn.

\section{Industrial Associations Act}

Trade unions usually represent employees of a single employer. However, employees can have more than one employer: workers may be seasonally employed, while workers in agriculture may be engaged by different employers at different periods of the production cycle, making it impossible to identify a single employer over the entire 
production period. In a similar vein, it may be difficult to clearly draw the line between employer and employee. For example, sugarcane farmers produce commodities that are sold to a central purchasing authority. While the central purchasing authority does not employ sugarcane farmers, they clearly have a hierarchical contractual relationship. In these sorts of circumstances, trade unions of the usual definition cannot be formed. Prior to 1991, in circumstances where a trade union was difficult to form, an industrial organisation could be formed to represent collective interests. The 1991 amendments to the Industrial Associations Act barred an industrial association registered under the Act from engaging in any trade dispute or matters connected with the regulation of relations between employees and employees, between employees and employers, or between employers and employers. The change thus restricted, if not eliminated, the capacity of an industrial association to represent collective interests.

As a consequence of this amendment, industrial associations could no longer register industrial disputes. This provision effectively eliminated the power of industrial associations in the sugar industry. These associations were amongst the most powerful of the groups supporting democracy that emerged after the 1987 coups; the amendment thus restricted dissent. The amendment also restricted the capacity of the Fiji Garment Workers Association to represent collective interests. According to a Ministry of Labour official, this 'ensured the garment industry complete freedom from interference by its workers. The effect has been a continuation of individual bargaining in an industry where possible unionisation of approximately 10,000 workers could pose a big threat to a comparatively new industry' (Khan 1994:8).

The amendments to the Industrial Associations Act were also designed to weaken the leadership of industrial associations. Under the amendments, an officer of an industrial association was prohibited from being an officer of another industrial association or of a trade union. This amendment was effectively intended to limit the power of particular trade union leaders who also held official positions in industrial associations. Commonly, these leaders were also active in the democracy movement. In a related amendment, the Registrar of Trade Unions was empowered to declare the election of a Secretary or a Treasurer as null and void on the grounds of the elected official lacking a formal education. A prohibition could also be placed on any person convicted of fraud, dishonesty or extortion. Such individuals 
were banned for 5 years from holding the position of an officer in an industrial association. While this latter amendment might at first glance appear appropriate, it must be seen within the context of the amendments as a whole; it could be used to bar officials who had breached the amended laws - such as holding dual offices-and who in so doing were found to be 'dishonest'.

\section{Trade Union (Recognition) Act}

The amendments to the Trade Union (Recognition) Act dealt with the provisions by which new trade unions could gain recognition. Prior to 1991, when 50 per cent of eligible employees joined a trade union and when there was no rival union a Compulsory Recognition Order could be obtained. This legally entrenched the position of the trade union. Under the amendments, when applying for a Compulsory Recognition Order the percentage of employees who had joined the union had to be based on the number of employees on the date of the application for recognition. The only exception was for those employees who left of their own accord. This amendment thus prevented employers from manipulating the 50 per cent requirement by either firing union members or hiring more non-union workers after the application for recognition had been made. This amendment was obviously to the benefit of trade unions. Many others, however, were not.

One amendment allowed the Permanent Secretary for Labour to exclude from recognition those employees who acted in a confidential capacity or in matters relating to industrial relations. Through this provision the govemment substantially reduced the number of potential union members in the labour force. Many categories of workers, including administrative and secretarial workers and supervisory and managerial workers, could be excluded from collective bargaining on the basis that they had to maintain confidentiality or that they dealt with staff matters.

A further amendment repealed provisions relating to the compulsory 'check-off' of trade union dues from members of recognised trade unions. Under the check-off provision, employers deducted union dues from pay packets and transferred the dues directly to the union. The repeal thus substantially weakened the financial base of trade unions, as it required financial officers of unions to collect dues from members individually on a weekly, fortnightly or monthly basis, a task which was cumbersome, in part because the fees charged by banks to 
deduct dues directly from bank accounts was more than the cost of union membership. While the amendment to the Trade Unions (Collection of Union Dues) Regulations allowed unions and employers to enter into agreements to allow for union dues to be deducted 'at source', the provision clearly favoured employers, in that employers could charge heavy fees for this facility.

Numerous unions and industrial associations felt the effect of the repeal of the check-off provision. A case in point is the Fiji Public Service Association (PSA), whose membership fell from approximately 4,500 in 1990 to about 2,800 by late 1992; the fall was to a large extent because of the repeal of the check-off provision. In its capacity as employer, the government negotiated with the PSA over the re-introduction of the check-off system. However, the government sought to drive a hard bargain. It sought a written undertaking from the PSA to acknowledge, support and endorse the labour reform decrees; abrogate the right to strike; cease seeking international solidarity for the trade union and democracy movement in Fiji; and bear the costs of the deduction. That the Government finally agreed in 1992 to maintain the check-off system without condition reflects the efforts of the PSA in the face of attempts clearly intended to severely limit the effectiveness of public sector unions.

In the private sector, following negotiations with employers many unions continued to use the check-off system. But 'the threat of withdrawal...hung over their heads' and 'could force them to compromise their demands' (Khan 1994:10). Indeed, refusal to agree to the maintenance of the check-off system effectively killed some private sector unions. An example was the Fiji Garment, Textile and Allied Workers Union. This was registered in 1992 but was unable to survive as the garment manufacturers refused to provide a check-off system (Khan 1994:10).

Yet another amendment empowered the Minister for Labour to declare as unlawful a strike or lockout over trade union recognition when, in the Minister's view, all procedures governing recognition had not been followed. The Minister was thus provided with discretionary power in declaring strikes concerning recognition unlawful. The effect of this was the elimination of strikes and lockouts over the issue of trade union recognition. The implication of this amendment went beyond recognition, however; in a dispute over wages or conditions an employer could challenge recognition as a means of restricting recourse to industrial action (International Labour Organization (ILO) 1992:161). 
Amendments regarding 'unlawful' strikes criminalised certain union activity. Thus, causing, procuring or counseling, or in any way encouraging, persuading or influencing others to take part in any strike, lock-out or boycott which had been declared unlawful were made criminal offences. Similarly, a cessation of work or a refusal to continue work in circumstances which gave rise to 'reasonable suspicion' that the worker was taking part in or acting in furtherance of an unlawful strike was made a criminal offence. A person found guilty of an offence relating to an unlawful strike was also barred from holding any post as an officer of a trade union for a period of two years from the date of committing the offence.

Finally, an amendment gave Ministry of Labour officials the power to demand employers' employment records and from trade unions trade union membership records. In the wake of the coups, and the political environment they created, such an amendment might be considered an infringement of freedom of association. In summary then, these amendments weakened union membership, union solidarity, and union leadership.

\section{Trade Unions Act}

Amendments to the Trade Unions Act brought about substantive changes in the industrial relations climate. A starting point was the redefinition of 'strike'. 'Strike' had previously been defined as a cessation of work. This definition was expanded to include go-slows, work-to-rule, the withdrawal of goodwill, breaches of contract of service, and refusing to accept engagement for any work in which the workers were usually employed. A parallel amendment to the Trade Disputes Act similarly extended the definition of strikes. These amendments eliminated the use of 'non-strike' tools as a means of pursuing industrial action.

A second change to the Trade Unions Act repealed the provision for disallowing the registration of unions where a union already existed. According to the Administrator General, Government policy had previously been to encourage horizontal industrial and sectorbased unions rather than 'in-house', plant-based, vertical unions. The result had been the rise of some very large unions which, according to the Administrator General, were 'too politically powerful and aligned so that quite often the interests of many of their members get forgotten...[I]n their internal workings, principles and etiquette's (sic) 
of democratic practices do not get observed' (FTUC files 1998). While the Administrator General stressed that the amendment was in line with the advice of the ILO's Committee of Experts and the ILO's Convention 87 , this amendment, together with a provision enabling a group of five or more workers to form a trade union, encouraged the formation of 'new' trade unions. This was clearly the purpose behind the amendment. Some of the 'new' unions were ethnically based, while others were management-sponsored. Thus, whereas between 1990 and 1991 only five new unions were registered, between 1992 and 1994, 14 new unions were registered (Chand 1996). Of the newly registered unions, nine were the result of splits within existing larger unions. The amendment thus reduced the power of large unions, and, according to the Administrator General, were expected to 'lead to the formation of a new union federation rival to FTUC' (FTUC files 1998). It comes as little surprise then that according to its General Secretary the provision-by allowing a gold mining company to sponsor a rival workers' council—aided the collapse of the Fiji Mine Workers Union (personal communication 1995). ${ }^{2}$

In a third change to the Trade Unions Act, the section covering immunity from civil prosecution as a consequence of trade union activities was repealed, with the exception of activities which had been endorsed in a secret ballot of union members conducted under the provisions of the labour legislation. As a consequence of this change, unions, officials and members could be sued for loss of output or damage to materials on account of 'illegal' strikes. The immediate impact of this amendment was that it reduced the number of 'wildcat' strikes from 25 in 1990 and 11 in 1991 to three in 1992 and six in 1993 (Khan 1994:12).

A fourth change was a new provision that required unions seeking international solidarity to get a mandate from their members through a secret ballot. The effect of this was to reduce, through delay, efforts designed to mobilise international support for workers' struggles in Fiji.

\section{Trade Unions Regulations}

The Trade Unions Regulations were amended to allow the government to supervise union ballots. The amendments allowed the government to report on the regularity of ballots and to intervene to prevent any irregularity in connection with ballots. An associated amendment required that unions seeking a ballot had to notify the 
Registrar of Trade Unions at least 21 days before the date of the ballot. Moreover, proxy voting was disallowed in any ballot concerning executive positions in a union. The amendments also placed a time restriction on the use of the ballot: once balloting concerning industrial action had been completed, the validity of a strike mandate was limited to six weeks. In addition, the amendments allowed the government, in its role as an employer, to directly supervise ballots in civil service unions.

The amendments thus served to limit the right of workers to conduct their affairs according to rules that they had drawn up. They also restricted the capacity of unions to immediately resort to industrial action when seeking to rectify grievances. In so doing, they violated workers' rights to freedom of assembly and organisation. Moreover, they also introduced a degree of arbitrariness into the industrial relations system: pro-regime unions which went on strike without fulfilling the necessary procedural requirements-like the Port Workers and Seafarers Union and the National Union of Factory and Commercial Workers Pacific Fishing Corporation branch-were not charged with violating trade union regulations, while anti-regime unions such as the Fiji Aviation Workers Association were charged with violating the law (Khan 1994:12).

\section{Trade Disputes Act}

There have been numerous smaller amendments to the Trades Disputes Act, which together constitute a significant rewriting of the Act. A first set of amendments served to distinguish between disputes of interests, which deal with the procurement of a collective agreement, and disputes of rights, which cover all other disputes. Separate procedural machinery for dealing with disputes of interests and disputes of rights were set up. This provision reduced the number of strikes on disputes of interests from an average of 7 per year between 1988 and 1990 to 2 per year for the years 1993 and 1994 (Khan 1994).

A second set of amendments disallowed individuals or groups of workers or unions who were unrecognised by the Registrar of Trade Unions from reporting trade disputes. As a consequence of this amendment, the Garment Workers Union could not file a trade dispute concerning check-off because it remained unrecognised. Similarly, the government did not recognise a dispute between Emperor Gold Mines 
and the Fiji Mine Workers Union because the employer had successfully challenged a compulsory recognition order from the Ministry of Labour.

A further amendment repealed the provision of representation by a lawyer in dispute and conciliation proceedings except those before the Arbitration Tribunal. The rationale was to reduce the involvement of outside parties such as lawyers, in order to resolve disputes more quickly. This had a possible benefit for unions because employers had a greater financial capacity to hire lawyers. However, this benefit was muted by the fact that employers could still obtain leave from the authorities to be represented by lawyers.

A key amendment of the Trade Unions Act was an expansion of the list of essential services. Essential services require a forty-nine day notice to the Ministry of Labour before any strike action; strikes thus become a more difficult tool for unions dealing with essential services. Indeed, since the Minister of Labour is empowered to order compulsory arbitration for disputes in essential services, the range of activities in which strikes become effectively redundant has increased as a result of the enlargement of the list of essential services.

\section{The impact of labour market reforms}

There can be little doubt that the labour market reforms of the early 1990s have had an impact on the functioning of the labour market. This section discusses this impact. In what follows, attention will be paid to unionisation rates, strikes and industrial disputes, wages and employee remuneration, and the structure of employment. The discussion is largely confined to the trends in these variables; no attempt is made to find a correlation between the reforms and the variables as this would require more detailed econometric testing.

\section{Unionisation}

A specific aim of the government when undertaking labour market deregulation was to weaken the influence of trade unions. The unionisation rate can be used as one indicator of the influence of unions. If used in this way, it is clear that deregulation has had significant success. First, union membership has plunged. Table 7.1 shows the unionisation rate in per cent between 1985 and 1995 for different economic sectors. 
In the period 1985-86 the overall unionisation rate was 45 per cent. This compares to a peak unionisation rate of 49 per cent in 1982. The rate declined to 37 per cent by 1995, a decline of 25 per cent (Chand 1996). It is of interest to note that the decline from $1985-86$ followed the imposition of the wage freeze in 1984, when structural adjustment policies began to be implemented in earnest, and when the capacity of unions to produce a key benefit—wage increments-was directly inhibited by government. Moreover, the decline in the unionisation rate has been systematic in all industrial sectors except mining, transport and finance. Indeed, even in mining union power has been reduced: a management-sponsored 'in-house' union has been created, weakening union autonomy.

The National Union of Factory and Commercial Workers (NUFCW) demonstrates the impact of labour market reforms on a large union. From a peak of 5,021 members in 1972, its membership declined to 2,270 by 1995 , a decline of about 50 per cent (Chand 1996). Most of this decline occurred during the structural adjustment period. The decline in the membership of the NUFCW was due to job reclassifications, which has resulted in a higher proportion of 'casual' workers; the formation of new plant-based unions; the collapse of certain branches in factories affected by trade liberalisation; and specific efforts at union busting by management. Labour law amendments empowered management further, thereby creating greater job uncertainty and fear amongst the workers of job losses if they resorted to trade unionism.

\section{Table 7.1 Unionisation rate by sector, per cent}

$\begin{array}{lrrr} & 1985-86 & 1988-91 & 1992-95 \\ \text { Agriculture } & 14.6 & 12.9 & 12.5 \\ \text { Mining } & 12.4 & 26.7 & 65.8 \\ \text { Manufacturing } & 48.8 & 27.7 & 24.2 \\ \text { Electricity } & 32.8 & 25.5 & 25.5 \\ \text { Construction } & 54.2 & 64.1 & 45.2 \\ \text { Wholesale/Retail } & 15.8 & 18.5 & 17.6 \\ \text { Transport } & 33.2 & 30.5 & 32.4 \\ \text { Finance } & 35.3 & 31.6 & 42.3 \\ \text { Services } & 64.8 & 58.8 & 54.9 \\ \text { Overall } & 45.2 & 38.4 & 36.6\end{array}$

Source: Chand, G., 1996. 'The labour market and labour institutions in Fiji in an era of globalisation and economic liberalisation', Fiji Trades Union Congress, Suva. 
Unionisation rates have also been affected by the already-noted changes in the Industrial Associations Act. One impact of the changes in the Act was to reclassify certain unions as associations, with the consequent 'loss' of thousands of union members. An example is the National Farmers Union: with the reclassification of the union as an association, statistics on unionisation dropped by about 3,000.

A significant aspect of unionisation in the era of labour reforms is that while the rate of unionisation has declined the number of trade unions has increased. In the years 1965 to 1990, 84 trade unions were registered; of these, 25 were cancelled, abandoned or amalgamated with other unions, leaving 59 registered unions. Of these, a maximum of 45 could be considered 'operational' in that they were active, and of these, 36 were affiliated to the FTUC. However, between 1991 and 1997 a total of 36 new unions were registered. Of these, at least 6 were breakaways from existing unions.

The increase is largely due to two factors. The first factor is management-sponsored workers' councils or plant-based unions encouraging sections of the workforce to splinter from existing unions in order to form a new collective bargaining unit. The second factor is turbulence within the FTUC during the period 1991-94. A group within the FTUC sought to gain control of it by actively forming new unions in order to weaken existing unions and, as a corollary, create a potential 'vote bank' for itself within the FTUC. This second factor ceased after 1994, when peace returned to the FTUC and unionsponsored breakaways ceased.

\section{Strikes and industrial disputes}

A central objective of the government in introducing changes to the labour laws was to reduce strikes and industrial disputes. Table 7.2 reports strike activity between 1970 and 1997. As Table 7.2

demonstrates, the average annual number of strikes during the period 1970-75 was 51; during the period 1978-84 it was 41 ; during the period 1988-90 it was 17; and during the period 1991-97, a mere 9. The decline from the 'Tripartite era' of 1978-84 to the era of labour reform of 1991-97 was 78 per cent; in the manufacturing sector the decline was 50 per cent. Table 7.2 also shows that the number of workers involved in strikes declined between the two periods. The number of working days lost, however, rose. The rise in the number of working days lost is explained by three specific strikes: the Fiji Bank 
Table 7.2 Strike activity, 1970-97

\begin{tabular}{lcccccc} 
& \multicolumn{2}{c}{ Overall strike activity } & \multicolumn{3}{c}{ In manufacturing } \\
& Number & Workers & Work Days & Number & Workers & Work Days \\
$1970-75$ & 51 & 7765 & 47846 & 6 & 1465 & 9938 \\
$1978-84$ & 41 & 3721 & 20970 & 6 & 1126 & 4283 \\
$1988-90$ & 17 & 1640 & 50433 & 9 & 826 & 40699 \\
$1991-97$ & 9 & 1763 & 36399 & 3 & 1009 & 11934
\end{tabular}

Source: Ministry of Labour records/Unpublished data held at Ministry of Labour, Suva.

Employees Union strike in 1996, involving 656 workers and 11 days; and the 1995 and 1997 Fiji Sugar and General Workers Union strikes, involving around 800 workers over 10 and 16 days respectively.

In terms of industrial disputes, Table 7.3 provides data on the number and nature of industrial disputes between 1980 and 1997. Table 7.3 demonstrates that disputes reported rose from 63 per year during the period 1980-86 to 102 per year during the labour reform era of 1991-97-an increase of 62 per cent. The basis of this increase is a jump in disputes relating to the dismissal of workers and the log of claims. Those relating to dismissals rose from 19 per year during the period 1980-86 to 34 per year during the labour reform era of 1991-97 -an increase of 79 per cent. The number of disputes relating to either a refusal to negotiate log of claims or disputes over the application of log of claims rose from 9 per year in the period 1980-86 to 30 per year in the period 1991-97-a jump of over 230 per cent. The jump in disputes on refusal to negotiate unions' log of claims can be explained in terms of the attitude of employers towards trade unions in the era of labour market reform, which re-asserted the philosophy that it is management's prerogative to exclusively determine the terms and conditions of employment, as well as a more aggressive approach by trade union leaders who had become discouraged over the lack of consultation about labour market deregulation at the firm as well as at the national level.

Table 7.4 provides evidence on modes of dispute resolution between 1980 and 1997. Table 7.4 demonstrates that in the period 1980-86 and 1991-97, there was a 48 per cent decline in the incidence of settlement through the conciliation machinery provided by the Ministry of Labour. At the same time, there was a 68 per cent increase in the resort to arbitration. Thus, reliance on conciliation mechanisms has declined significantly during the era of labour market reforms. 


\section{Table 7.3 Number, nature and composition of disputes}

\begin{tabular}{lrcrrrr} 
& \multicolumn{3}{c}{$1980-86$} & & \multicolumn{3}{c}{$1991-97$} \\
& Total & $\%$ & Yearly & Total & $\%$ & Yearly \\
Dismissal of workers & 135 & 31 & 19 & 239 & 33 & 34 \\
Log of claims negotiation & 62 & 14 & 9 & 212 & 30 & 30 \\
Conditions of employment & 61 & 14 & 9 & 40 & 6 & 6 \\
Non-payment & 63 & 14 & 9 & 4 & 0 & 1 \\
Breach-collective agreement & 50 & 11 & 8 & 162 & 23 & 23 \\
Job evaluation & 7 & 2 & 1 & 1 & 0 & 0 \\
Others & 62 & 14 & 9 & 55 & 0 & 8 \\
TOTAL & 439 & 100 & 63 & 713 & 100 & 102
\end{tabular}

Note: From 1993, job evaluation related disputes were merged with others, while nonpayment was merged with breaches of collective agreements. 'Others' include disputes over redundancies.

Source: Ministry of Labour records/Unpublished data held at Ministry of Labour, Suva.

The effect of labour market reform has therefore been to increase reliance on arbitration to settle industrial disputes. The arbitration mechanism for the settlement of disputes was established by the Trade Disputes Act, which provided for one or more arbitrators to resolve disputes. A key reason for the increasing reliance on arbitration procedure in the era of labour market reform is that the incidence of non-agreement has increased. With the rapid rise of a professional cadre of unionists seeking to justify their positions and pay, with the establishment of a new generation of management asserting its right to make decisions, and with an inability of the government to keep pace with the negotiation and analytical skills of employers and unions, seeking a binding solution from an arbitrator often seems preferable to conciliation. As a past Arbitration Tribunal put it, the 'process has made an excuse for avoiding or evading extensive negotiations and conciliation' (Madraiwiwi 1994:6).

\section{Wage and salary trends}

Table 7.5 provides evidence on trends in real wages between 1972 and 1996, using the wage settlements of the 1977-84 Tripartite era as the basis of a comparative index. Table 7.5 demonstrates that while the mining sector did particularly well during the labour reform era of 
Table 7.4 Dispute resolution

\begin{tabular}{lrrrrrr} 
& \multicolumn{3}{c}{$1980-86$} & & \multicolumn{3}{c}{$1991-97$} \\
& Total & $\%$ & Yearly & Total & $\%$ & Yearly \\
Voluntary arbitration & 95 & 23 & 14 & 41 & 6 & 6 \\
Compulsory arbitration & 3 & 1 & 0.4 & 124 & 17 & 18 \\
Industrial Relations Committee & 13 & 3 & 2 & 106 & 15 & 15 \\
Conciliation Machinery & 240 & 58 & 34 & 124 & 17 & 18 \\
Pending & 38 & 9 & 5 & 72 & 10 & 10 \\
Withdrawn & 11 & 3 & 2 & 74 & 10 & 10 \\
Dead Locked & 17 & 4 & 2 & 21 & 3 & 3 \\
Rejected & 0 & 0 & 0 & 97 & 14 & 14 \\
Sent back to parties & 0 & 0 & 0 & 44 & 6 & 6 \\
Other & 0 & 0 & 0 & 14 & 2 & 2 \\
Total & 417 & 100 & 60 & 717 & 100 & 102
\end{tabular}

Sources: Chand, G., 1996. 'The labour market and labour institutions in Fiji in an era of globalisation and economic liberalisation', Fiji Trades Union Congress, Suva; Ministry of Labour records/Unpublished data held at Ministry of Labour, Suva.

1992-96, so too did electricity, commerce and agriculture. However, with the exception of commerce, the sectors where the private sector predominates-manufacturing, construction, and transport-fared badly during the labour reform era. The manufacturing sector showed a marked decline; its average real wages were only 68 per cent of the 1977-84 level in the period 1992-96. Overall, Table 7.5 shows that there was a decline in real wages during the era of labour market reform between 1992 and 1996.

Table 7.6 displays salary data for the period 1970-96. It shows that, in general, the era of labour market reform from 1992 to 1996 has produced gains for salaried workers when compared to the immediate post-coup period. This is particularly the case for private sector workers with scarce skills, such as professional and technical workers. The trend away from national-level salary setting through Tripartite mechanisms and towards enterprise-based bargaining could be one reason for the improvement in relative salaries. However, the key finding of Table 7.6 is that real salaries in the era of labour market reform have, in general, declined when compared to those in of the Tripartite era salaries. The exceptions to this trend are the agriculture, mining and transport sectors. 
Table 7.5 Real wage ratios

$\begin{array}{lrrrrr} & 1972-76 & 1977-84 & 1985-86 & 1987-91 & 1992-96 \\ \text { Agriculture } & 102 & 100 & 87 & 86 & 91 \\ \text { Mining } & 102 & 100 & 92 & 92 & 114 \\ \text { Manufacturing } & 90 & 100 & 90 & 72 & 68 \\ \text { Electricity } & 83 & 100 & 100 & 89 & 94 \\ \text { Construction } & 92 & 100 & 91 & 84 & 83 \\ \text { Commerce } & 94 & 100 & 91 & 79 & 84 \\ \text { Transport } & 91 & 100 & 95 & 86 & 84 \\ \text { Services } & 91 & 100 & 92 & 81 & 81 \\ \text { Overall } & 91 & 100 & 92 & 80 & 79\end{array}$

Note: The data expresses real wages as a percentage of the average 1977-84 real wage. Real wage data is the average daily wage rate deflated by the consumer prices index. The base year is 1972 .

Source: Fiji Bureau of Statistics, (various issues). Current Economic Statistics, Government Printer, Suva; Annual Employment Survey, Government Printer, Suva.

Table 7.6 Real salary ratios

$\begin{array}{lrrrrr} & 1970-76 & 1977-84 & 1985-86 & 1987-91 & 1992-96 \\ \text { Agriculture } & 92 & 100 & 97 & 95 & 118 \\ \text { Mining } & 124 & 100 & 87 & 125 & 141 \\ \text { Manufacturing } & 94 & 100 & 98 & 92 & 94 \\ \text { Electricity } & 92 & 100 & 87 & 80 & 89 \\ \text { Construction } & 99 & 100 & 78 & 72 & 83 \\ \text { Commerce } & 103 & 100 & 98 & 92 & 96 \\ \text { Transport } & 85 & 100 & 105 & 91 & 105 \\ \text { Finance } & 94 & 100 & 98 & 92 & 98 \\ \text { Services } & 84 & 100 & 112 & 91 & 95 \\ \text { Overall } & 88 & 100 & 105 & 90 & 96\end{array}$

Note: The data expresses real salaries as a percentage of the average real salary for the period 1977-84. Real salary data is the average annual salary deflated by the consumer prices index. The base year is 1970 .

Source: Fiji Bureau of Statistics, (various issues). Current Economic Statistics,

Government Printer, Suva; Annual Employment Survey, Government Printer, Suva.

\section{Employment structure and gender differentials}

It can be hypothesised that the deregulation of the labour market might have had an impact on the structure of employment in Fiji. Moreover, it might be hypothesised that the increasing commercialisation of the economy under adjustment might have led to an increasing proportion of females in the labour force: the increased 
availability of jobs perceived to be predominantly for females and the decline in the relative number of 'traditional male jobs', like those in commercial agriculture, would tend to attract more females into the labour market. These propositions are examined in Tables 7.7 and 7.8. Table 7.7 gives the sectoral composition of employment by gender for the period 1980-93. Table 7.8 gives the structure of wage and salary remuneration by gender for the period 1980-93.

Table 7.7 shows that the female share of formal employment has increased from 20 per cent of total employment in 1980 to 31 per cent of total employment in 1993. Within the increasing 'feminisation' of the labour force, there has been a particularly sharp jump in the proportion of females working in the manufacturing sector (Table 7.7). In 1986 the share of females in total manufacturing sector employment was 16 per cent. By 1993, the female share of total manufacturing employment had doubled, to stand at 32 per cent. This dramatic increase is the result of economic policy. The shift to export-oriented industrialisation in Fiji under structural adjustment was largely based on garment and footwear processing in 'tax-free' manufacturing sites which were actively promoted by government policy; both these industries grew rapidly following the coups, just as both these industries relied predominantly on female labour.

\section{Table 7.7 The sectoral composition of employment by gender}

$\begin{array}{ccccc}\text { Year } & \begin{array}{c}\text { \% of females } \\ \text { in manufacturing }\end{array} & \begin{array}{c}\text { \% of females } \\ \text { in distribution }\end{array} & \begin{array}{c}\text { Total females } \\ \text { in employment }\end{array} & \begin{array}{c}\text { Female labour } \\ \text { force (\% of total) }\end{array} \\ 1980 & 10.3 & 24.7 & 14402 & 20.29 \\ 1981 & 11.1 & 22.2 & 15516 & 22.04 \\ 1982 & 10.7 & 23.3 & 14613 & 21.81 \\ 1983 & 13.0 & 24.3 & 15814 & 22.42 \\ 1984 & 13.3 & 23.7 & 17117 & 22.91 \\ 1985 & 13.8 & 22.0 & 19027 & 24.60 \\ 1986 & 15.6 & 20.8 & 18999 & 25.09 \\ 1987 & 18.9 & 18.3 & 19563 & 26.14 \\ 1988 & 20.2 & 18.9 & 19655 & 26.94 \\ 1989 & 28.7 & 18.4 & 24725 & 29.35 \\ 1993 & 32.3 & 18.8 & 31126 & 30.50\end{array}$

Source: Devi, P. and Chand, G., 1997. 'Female employment and earnings' in G. Chand and V. Naidu (eds), Fiji: coups, crises, and reconciliation, 1987-1997, Fiji Institute of Applied Studies, Suva. 
The increasing feminisation of the workforce is essentially taking place in the private sector. Indeed, there has been a decline in the share of females employed in the public sector, from 45 per cent of total employment in 1986 to 29 per cent of total employment in 1993 (Devi and Chand 1997). Public sector jobs are, comparatively speaking, more secure than private sector jobs; thus, the feminisation of the workforce and the predominance of females in the private sector also suggests increasing employment insecurity.

In addition to a possible increase in employment insecurity, the feminisation of the labour force has not been accompanied by a shift into the 'salariat' by females. Salaried jobs carry relatively greater stability, greater job-related benefits, better fringe benefits, better prospects of upward mobility, greater authority, and more social prominence. They are, in short, more 'desirable'. Table 7.8 shows the female share of total wage employees rose from 14 per cent in 1980 to 28 per cent in 1993. By way of contrast, in salaried employment the female share of total employment rose from only 31 per cent in 1980 to 34 per cent in 1993. Moreover, this trend peaked in 1985, and remained reasonably unchanged thereafter. Thus, while female employment over the period has increased, the concentration of female workers in

\section{Table 7.8 Wage and salary structure by gender}

\begin{tabular}{lrrrr} 
& \multicolumn{2}{c}{ Wage employment } & \multicolumn{2}{c}{ Salaried employment } \\
\% females & \% males & \% females & $\%$ males \\
1980 & 13.9 & 86.1 & 30.5 & 69.5 \\
1981 & 15.4 & 84.6 & 31.2 & 68.8 \\
1982 & 16.6 & 83.4 & 28.6 & 71.4 \\
1983 & 16.7 & 83.3 & 30.2 & 69.8 \\
1984 & 17.1 & 82.9 & 30.4 & 69.6 \\
1985 & 17.1 & 82.9 & 34.7 & 65.3 \\
1986 & 18.1 & 81.9 & 34.3 & 65.7 \\
1987 & 20.7 & 79.3 & 33.2 & 66.8 \\
1988 & 22.2 & 77.8 & 32.6 & 67.4 \\
1989 & 27.2 & 72.8 & 32.3 & 67.7 \\
1993 & 28.1 & 71.9 & 34.1 & 65.9 \\
Averages: & & & & \\
$1980-86$ & 16.4 & 83.6 & 31.4 & 68.6 \\
$1887-93$ & 24.6 & 75.5 & 33.1 & 67.0
\end{tabular}

Source: Devi, P. and Chand, G., 1997. 'Female employment and earnings' in G. Chand and V. Naidu (eds), Fiji: coups, crises, and reconciliation, 1987-1997, Fiji Institute of Applied Studies, Suva. 
relatively more desirable jobs has stabilised. Moreover, in terms of earnings, female earnings as a proportion of national income have increased by only 0.7 per cent between the 1980-86 and 1987-93 periods (Devi and Chand 1997). Almost the entirety of this minimal rise has been due to the rise in the female wage earnings component of national income. In summary, it is clear that in Fiji women are increasingly becoming a cornerstone of the working class, and that in part the reason for this structural change is, simply, that women are paid less than men.

\section{Ethnic differentials}

It can be hypothesised that labour market reforms would also have had an impact on ethnic differentials in the labour market. Concrete evidence of ethnic differentials requires employment and earnings data by ethnic categories, but these are not available. Nonetheless, three comments can be made.

The first comment is that, as noted earlier, the reforms were brought in following the coups; one purpose behind the weakening of what were predominantly multiethnic trade unions was to increase the role of ethnicity in Fiji society, and thereby weaken anti-regime forces. As a consequence, it might be expected that labour market reform would have had an impact on ethnic differentials. It is in part for this reason that unions with a predominantly Indo-Fijian membership base-like the National Farmers Union-were specifically targeted by the amendments. However, in most instances the expected outcome did not materialise. In the case of the National Farmers Union, the union remained strong, vibrant and multiethnic, largely because of its strength in the sugar industry.

The second comment is that despite ongoing centers of trade union strength, the reforms have succeeded in creating labour market conditions in which individual workers have become relatively vulnerable, and this may have had an ethnic dimension. In its 1998 Country Report on Human Rights Practices, the US Department of State (1999:15) noted that 'Indo-Fijians, who generally require a cash income to survive, are more vulnerable to pressure to work long hours than are ethnic Fijians. Many ethnic Fijians can and do return to their villages rather than work what they consider excessive hours'. In a sense then, the greater reliance on the cash economy found within the Indo-Fijian community may, in the context of labour market reforms, have increased the vulnerability of the Indo-Fijian community. 
The third comment supports this point. Public sector jobs in Fiji are dominated by indigenous Fijians, while private sector jobs are dominated by Indo-Fijians. Given that labour market reforms negatively affected private sector employment and earnings more than they affected the public sector, Indo-Fijian workers have possibly been subject to a more severe impact than indigenous Fijians.

In summary, while definitive evidence on the ethnic impact of labour market reforms has yet to emerge, there is reason to believe that the reforms have had a larger impact upon the Indo-Fijian labour force.

\section{The new constitutional settlement}

The operation of the labour market has changed significantly since the labour legislation amendments of the early 1990s. Expecting a significant deterioration in the state of trade unionism, the trade union movement launched an intensive campaign against the amendments. Internationally, the FTUC, through the International Confederation of Free Trade Unions and the Public Services International, lodged complaints to the ILO. The ILO rejected many of the FTUC's complaints; these included the administrative restrictions on recognition, the exclusion of certain categories of workers from recognition, the notice and secrecy requirement governing strike action, and the removal of compulsory check-off facilities. The ILO accepted the other complaints of the FTUC and asked the Government to amend the amendments 'so as to leave the necessary autonomy to worker's organisations' (ILO 1992:174).

The government did not take any serious step to meet any of the ILO's recommendations on amending the labour law amendments until July 1997, when the Constitution (Amendment) Act was passed by Parliament. The resulting new Constitution has already had a significant effect upon the industrial relations framework in Fiji. This is because of the fact that under Section 195 all decrees relating to labour legislation, except those amending the Trade Disputes Act, the Trade Unions Act, and the Trade Unions (Recognition) Regulations, have been repealed. The amendments that were not repealed concern trade disputes, voting and union dues.

At the same time, the Constitution (Amendment) Act represents a significant advance for labour when compared to other constitutions. In previous constitutions, labour relations were covered under the 'Protection of Freedom of Assembly and Association' provisions of the 
chapter on the 'Protection of Fundamental Rights and Freedoms of the Individual'. For example, the specific provision in Section 14(1) of the 1990 Constitution was

Except with his own consent, no person shall be hindered in the enjoyment of his freedom of assembly and association, that is to say, his right to assemble freely and associate with other persons and in particular to form or belong to trade unions or other associations for the protection of his interests.

Under the 1997 Constitution a specific section is devoted to labour relations. Section 33 of the new Constitution specifically provides for the right to collectively organise and bargain. It states

(1) Workers have the right to form and join trade unions, and employers have the right to form and join employers' organisations.

(2) Workers and employers have the right to organise and bargain collectively.

(3) Every person has the right to fair labour practices, including humane treatment and proper working conditions.

The provision of these rights is a major achievement for labour in Fiji, in that legislation must be consistent with the Constitution. The right to bargain collectively presupposes union recognition. The latter presupposes the existence of a union. Moreover, it is possible, even likely, that those 1991 and 1992 amendments which were not repealed under the new constitutional settlement may eventually be deemed to be inconsistent with the provisions of the Constitution.

Nonetheless, the optimism engendered by the new constitutional settlement must be tempered. The 1997 Constitution will affect a labour market that operates in a very different way from that which existed prior to the amendments of the early 1990s. It remains to be seen whether the 'success' of the labour market reforms of the early 1990s will effectively reduce or indeed negate the impact of the new Constitution on the operation of the labour market.

\section{Conclusion}

This chapter has examined labour market deregulation in Fiji. Tracing the background to the deregulation policies, the chapter has documented the objectives of the deregulation drive, the key mechanisms for deregulating the labour market, and some 
consequences of the deregulation. It has been argued that the deregulation of the labour market was a central part of the wider structural adjustment policies that Fiji began adopting in the mid 1980s. The military coups and the subsequent collapse of the economy provided the opportunity for Fiji to push ahead with the adjustment program. Since the basis of the adjustment program was exportoriented industrialisation, and this required, in the view of the government, a wage-competitive economy, the government attempted to restructure the operation of labour market in order to foster wage competitiveness. A second central objective was to reduce the power of trade unions, since many trade union leaders were leading the democratic movement in Fiji.

To this end, labour laws were amended by decrees and national wage settlement mechanisms terminated. Deregulation had, in broad terms, four consequences. The first was that the decline in the unionisation rate, which had begun in the early 1980s, rapidly accelerated, particularly in the manufacturing and construction sectors. The second consequence was that while both the number and intensity of strikes fell significantly, industrial disputes increased as the conciliation machinery provided by the Ministry of Labour fell into disuse, being replaced by the resort to arbitration. The third consequence has been an overall decline in real wages, particularly in the manufacturing, construction and transport sectors-sectors where the private sector dominates. The fourth consequence has been a change in the employment structure, where there has been a significant increase in the number of women employed in low-paid jobs, particularly in the manufacturing sector, and specifically in the garment and footwear industries.

The new Constitution has repealed some of the decrees that were promulgated during 1991 and 1992. However, this has occurred after a significant transformation in Fiji's labour market. Despite the already apparent consequences of this transformation, the long-term impact is not clear. What is clear, however, is that labour markets have never operated according to the principles of neoclassical economics. Even if 'distortions', in the form of trade unions, were not present, the mere fact that the agents entering into the bargaining process do so with vastly unequal economic strength implies that the terms and conditions of negotiation are affected by the economic strength of the agents who are undertaking the negotiation. Power hierarchies thus 
structure the operation of the labour market, and it is for this reason that there is a role for the state. The state provides the institutional framework within which the labour market operates, and thus within which negotiations between unequally endowed agents occur. When the institutional framework reflects the collective will of the citizenry, labour market outcomes will usually be regarded by the various participants as 'just'. When the institutional framework does not reflect the will of the people, labour market outcomes will not be regarded as just. There can be little doubt that the new Constitution, in repealing many of the labour legislation amendments of the early 1990s, suggests that the institutional framework structuring labour market outcomes in the early 1990s was regarded, by many of the peoples of Fiji, as unjust. This may in turn help in part explain the outcome of the 1999 general elections. The past can be undone; but whether the peoples of Fiji continue to choose to do so remains to be seen.

\section{Endnotes}

1. Fiji Trades Union Congress files held at the FTUC Building, Suva.

2. Transcribed interview with the General Secretary of the Fiji Mine Workers Union, 1995. 
This text is taken from Confronting Fiji Futures, edited by A. Haroon Akram-Lodhi, published 2016 by ANU eView, The Australian National University, Canberra, Australia. 